This document was prepared in conjunction with work accomplished under Contract No. DE-AC09-96SR18500 with the U.S. Department of Energy.

This work was prepared under an agreement with and funded by the U.S. Government. Neither the U. S. Government or its employees, nor any of its contractors, subcontractors or their employees, makes any express or implied: 1 . warranty or assumes any legal liability for the accuracy, completeness, or for the use or results of such use of any information, product, or process disclosed; or 2 . representation that such use or results of such use would not infringe privately owned rights; or 3 . endorsement or recommendation of any specifically identified commercial product, process, or service. Any views and opinions of authors expressed in this work do not necessarily state or reflect those of the United States Government, or its contractors, or subcontractors. 


\title{
The Hydrolysis and Oxidation Behavior of Lithium Borohydride and Magnesium Hydride $\left(\mathrm{LiBH}_{4} \mathrm{MgH}_{2}\right)$ Determined by Calorimetry
}

\author{
Kyle S. Brinkman, Joshua R. Gray, Bruce Hardy, and Donald L. Anton \\ Savannah River National Laboratory \\ WSRC-STI-2008-00155
}

\begin{abstract}
Lithium borohydride, magnesium hydride and the 2:1 "destabilized" ball milled mixtures ( $2 \mathrm{LiBH}_{4}: \mathrm{MgH}_{2}$ ) underwent liquid phase hydrolysis, gas phase hydrolysis and air oxidation reactions monitored by isothermal calorimetry. The experimentally determined heats of reaction and resulting products were compared with those theoretically predicted using thermodynamic databases. Results showed a discrepancy between the predicted and observed hydrolysis and oxidation products due to both kinetic limitations and to the significant amorphous character of observed reaction products. Gas phase and liquid phase hydrolysis were the dominant reactions in $2 \mathrm{LiBH}_{4}: \mathrm{MgH}_{2}$ with approximately the same total energy release and reaction products; liquid phase hydrolysis displayed the maximum heat flow for likely environmental exposure with a peak energy release of $6(\mathrm{~mW} / \mathrm{mg})$.
\end{abstract}

\section{INTRODUCTION}

In order to design commercially viable solid state hydrogen storage systems, it is important to understand and quantify the environmental reactivity of the active species in possible environmental exposure scenarios. The "destabilized" mixture of $2 \mathrm{LiBH}_{4}: \mathrm{MgH}_{2}$ has been reported to exhibit $>10 \mathrm{wt} \% \mathrm{H}$ capacity while being rechargeable under the constraints of reasonable pressure and temperature ( 1 to $10 \mathrm{~atm}$ and 20 to $\left.100^{\circ} \mathrm{C}\right)[1]$. This material system is currently one of a number of leading candidate materials for solid state hydrogen storage[2]. The hydrolysis of compounds such as sodium borohydride has been a topic of intense focus for hydrogen generation, however much less is understood about the hydrolysis and oxidation under environmental exposure scenarios[3]. This report aims to fill that gap by presenting a summary of thermodynamic calculations and substantiating calorimetric experiments performed in order to quantify both the rate and the amount of the energy released; as well as characterize the reaction products resulting from water and air exposure of $2 \mathrm{LiBH}_{4}: \mathrm{MgH}_{2}$.

\section{EXPERIMENTAL}

$\mathrm{LiBH}_{4}$ and $\mathrm{MgH}_{2}$ (Aldrich) were studied individually in the as-received forms as well as the 2:1 "destabilized" ball milled mixture[1]. Materials were characterized in the fully hydrided state and hydrolysis was performed in a Calvet calorimeter (Setaram C-80) equipped with a mixing cell using both neutral and acid water to react nominally 5-10 mg of solid with $1 \mathrm{ml}$ of liquid. Gas phase reactivity examining oxidation and gas phase hydrolysis was performed at varying relative humidity levels and temperatures using the calorimeter equipped with a flow cell using argon or air as the carrier gas with a flow rate of $10 \mathrm{ml} / \mathrm{min}$ reacting with nominally 5-10 $\mathrm{mg}$ of solid. X-ray diffraction analysis characterizing the crystalline content of the starting 
material and environmental reaction products were performed after drying materials at ambient conditions.

\section{RESULTS}

\section{Thermodynamic calculations}

Environmental exposure to air, water vapor and liquid water has been simulated using thermodynamic databases and the software HSC[4]. Figure 1. displays the Gibbs free energy ( $\Delta \mathrm{G} \mathrm{kJ} / \mathrm{mol}$ ) versus temperature for possible reactions resulting from the exposure of the starting material 2 $\mathrm{LiBH}_{4}: \mathrm{MgH}_{2}$ to liquid water $\left(\mathrm{H}_{2} \mathrm{O}\right)$. As indicated in Figure 1., Lithium hydroxide ( $\mathrm{LiOH}$ ), magnesium dihydroxide $\mathrm{Mg}(\mathrm{OH})_{2}$, boronic acid $\mathrm{H}_{3} \mathrm{BO}_{2}$ and gaseous hydrogen are the predicted lowest energy products which should form via the hydrolysis reaction. These calculations have been also been performed for exposure to dry air (essentially reaction with oxygen) and humid air (water vapor) as a function of temperature. The reactions leading to the lowest Gibbs free energy are indicated in Table 1. along with the thermodynamically predicted heat of reaction.

In general, the reaction with oxygen has a lower free energy and is thus favored over the reaction with water vapor. The lowest energy products from air reactions are predicted to be $\mathrm{LiOH}, \mathrm{Mg}(\mathrm{OH})_{2}$ and $\mathrm{H}_{3} \mathrm{BO}_{2}$ or $\mathrm{B}(\mathrm{OH})_{3}$ (these products give similar energy). The reaction witwater gives similar predictions for $\mathrm{LiOH}$ and $\mathrm{Mg}(\mathrm{OH})_{2}$ compounds, however the $\mathrm{H}_{3} \mathrm{BO}_{2}$ product is the energetically favored boron containing reaction product.

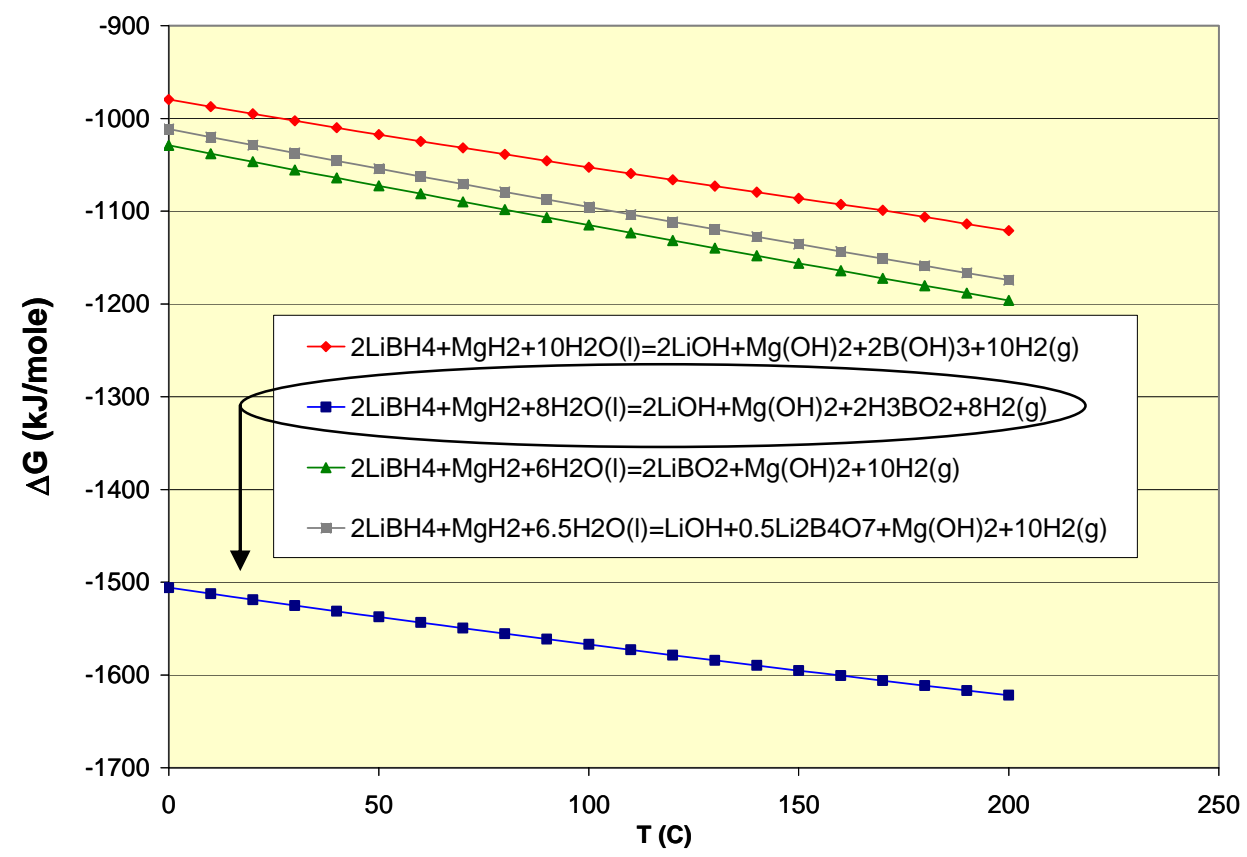

Figure 1: Gibbs Free energy of reaction $\Delta \mathrm{G}(\mathrm{kJ} / \mathrm{mole})$ versus temperature for exposure of $2 \mathrm{LiBH}_{4} * \mathrm{MgH}_{2}$ to water (hydrolysis). Lowest energy reaction predicted to produce $\mathrm{LiOH}$, $\mathrm{Mg}(\mathrm{OH})_{2}, \mathrm{H}_{3} \mathrm{BO}_{2}$ and $\mathrm{H}_{2}(\mathrm{~g})$ with a exothermic reaction enthalpy of $-1351 \mathrm{~kJ} / \mathrm{mole}$ (formula unit $2 \mathrm{LiBH}_{4}: \mathrm{MgH}_{2}$ ). 
Table 1: Thermodynamic calculations for environmental air and water exposure

\begin{tabular}{|c|c|c|c|}
\hline Material System & $\begin{array}{l}\text { Environmental } \\
\text { Exposure }\end{array}$ & Lowest Energy Reaction & $\begin{array}{c}\Delta G(\boldsymbol{k J} / \mathbf{m o l e}), \Delta \mathrm{H}(\mathrm{kJ} / \mathrm{mole}) \text { at } \\
373 \mathrm{~K}\end{array}$ \\
\hline \multirow[b]{2}{*}{$\mathrm{LiBH}_{4}$} & $\mathrm{H}_{2} \mathrm{O}$ (liquid) & $\mathrm{LiBH}_{4}+2 \mathrm{H}_{2} \mathrm{O}(\mathrm{l})=4 \mathrm{H}_{2}(\mathrm{~g})+\mathrm{LiBO}_{2}$ & $-390,-261$ \\
\hline & $\mathrm{O}_{2}$ & $\mathrm{LiBH}_{4}+1.5 \mathrm{O}_{2}(\mathrm{~g})=\mathrm{LiOH}+\mathrm{H}_{3} \mathrm{BO}_{2}$ & $-1292,-1386$ \\
\hline \multirow[b]{2}{*}{$\mathrm{MgH}_{2}$} & $\mathrm{H}_{2} \mathrm{O}$ (liquid) & $\mathrm{MgH}_{2}+2 \mathrm{H}_{2} \mathrm{O}(\mathrm{l})=\mathrm{Mg}(\mathrm{OH})_{2}+2 \mathrm{H}_{2}(\mathrm{~g})$ & $-334,-280$ \\
\hline & $\mathrm{O}_{2}$ & $\mathrm{MgH}_{2}+\mathrm{O}_{2}(\mathrm{~g})=\mathrm{Mg}(\mathrm{OH})_{2}$ & $-784,-847$ \\
\hline \multirow{2}{*}{$\begin{array}{c}\mathrm{LiBH}_{4} * 1 / 2 \mathrm{MgH}_{2} \\
\left\{2 / 3 \mathrm{LiBH}_{4}\right. \\
\left.* 1 / 3 \mathrm{MgH}_{2}\right\}\end{array}$} & $\mathrm{H}_{2} \mathrm{O}$ (liquid) & $\begin{array}{l}\mathrm{LiBH}_{4}+1 / 2 \mathrm{MgH}_{2}+4 \mathrm{H}_{2} \mathrm{O}(\mathrm{l})=\mathrm{LiOH} \\
+1 / 2 \mathrm{Mg}(\mathrm{OH})_{2}+\mathrm{H}_{3} \mathrm{BO}_{2}+4 \mathrm{H}_{2}(\mathrm{~g})\end{array}$ & $\begin{array}{r}-783,-675 \\
\{-450\}\end{array}$ \\
\hline & $\mathrm{O}_{2}$ & $\begin{array}{l}\mathrm{LiBH}_{4}+1 / 2 \mathrm{MgH}_{2}+2 \mathrm{O}_{2}(\mathrm{~g})=\mathrm{LiOH}+ \\
1 / 2 \mathrm{Mg}(\mathrm{OH})_{2}+\mathrm{H}_{3} \mathrm{BO}_{2}\end{array}$ & $\begin{array}{r}-1684,-1810 \\
\{-1207\} \\
\end{array}$ \\
\hline
\end{tabular}

An examination of the reactions occurring with liquid as compared to water vapor show that the $\Delta \mathrm{G}$ and predicted reaction products are the same, however the enthalpy of reaction $\Delta \mathrm{H}$ would be greater with water vapor at temperatures above $100^{\circ} \mathrm{C}$. Liquid water at atmospheric pressure would undergo an endothermic phase change, thus reducing the reaction enthalpy by the $41 \mathrm{~kJ} / \mathrm{mol}\left(\Delta \mathrm{H}\right.$ water $\left.100^{\circ} \mathrm{C}\right)$ multiplied by the stoichiometric amount of water in the reaction. For example, for the first material listed in Table 1 ., $\mathrm{LiBH}_{4}$, the vapor $\Delta \mathrm{H}$ would be $2 *(41$ $\mathrm{kJ} / \mathrm{mol}$ ) or $82 \mathrm{~kJ} / \mathrm{mol}$ less $(-353 \mathrm{~kJ} / \mathrm{mol})$, therefore more exothermic than the hydrolysis with liquid water. It is also noted that for leaks or ruptures leading to environmental exposure the extent of reaction may be limited by insufficient contact with water or air, leading to partial reactions. For instance, below $100^{\circ} \mathrm{C}$ the quantity of water vapor in air is fixed by equilibrium as a function of temperature. The reactions of the destabilized mix $2 \mathrm{LiBH}_{4}: \mathrm{MgH}_{2}$ are presented in Table 1 via the formula as written $\left(\mathrm{LiBH}_{4}+1 / 2 \mathrm{MgH}_{2}\right)$ and have also have been normalized to one mol of starting component $\left\{2 / 3 \mathrm{LiBH}_{4}+1 / 3 \mathrm{MgH}_{2}\right\}$ to facilitate comparison with the pure components $\mathrm{LiBH}_{4}$ and $\mathrm{MgH}_{2}$.

\section{Liquid mixing cell}

The heat of reaction during hydrolysis for the single components $\mathrm{MgH}_{2}, \mathrm{LiBH}_{4}$ and the mixture $2 \mathrm{LiBH}_{4}: \mathrm{MgH}_{2}$ were measured in a mixing cell using both neutral deionized (DI) water and a $1 \mathrm{M}$ hydrochloric $(\mathrm{HCl})$ acid solution. Figure 1. displays the maximum heat flow normalized per weight of hydride material $(\mathrm{mW} / \mathrm{mg})$ under acidic and neutral hydrolysis conditions. The remarkable increase of the reaction under acidic conditions points to the role of a hydroxide and/or oxide layer which may form on the surface of hydride particles in solution. This surface layer impedes the hydrolysis in neutral conditions, however strong acidic solutions seem to remove this layer allowing for quick reaction times. This effect has previously been observed in the magnesium hydride system [5]. The effect of environmentally accessible conditions such as acid rain ( $\mathrm{pH} 4$ ) displayed similar results to neutral water.

Both the total amount of heat released and the resulting reaction products were different after reaction with water and acid indicating different reaction pathways. Acid hydrolysis with $1 \mathrm{M} \mathrm{HCl}$ resulted in an amorphous lithium, plus magnesium boron hydroxide hydrate $\left(\mathrm{MgB}_{3} \mathrm{O}_{3}(\mathrm{OH})_{4} * 5 \mathrm{H}_{2} \mathrm{O}\right.$ with a total measured heat release of $-132 \mathrm{~kJ} / \mathrm{mol}$ (exothermic). Water 
hydrolysis resulted in a lithium boron hydroxide $\mathrm{LiB}(\mathrm{OH})_{4}$ and aqua lithium boron hydroxide hydrate $\mathrm{Li}\left(\mathrm{H}_{2} \mathrm{O}\right)_{4}\left(\mathrm{~B}(\mathrm{OH})_{4}\right)\left(\mathrm{H}_{2} \mathrm{O}\right)_{2}$, plus magnesium hydroxide $\mathrm{Mg}(\mathrm{OH})_{2}$ product with a total heat release of $-223 \mathrm{~kJ} / \mathrm{mol}$.

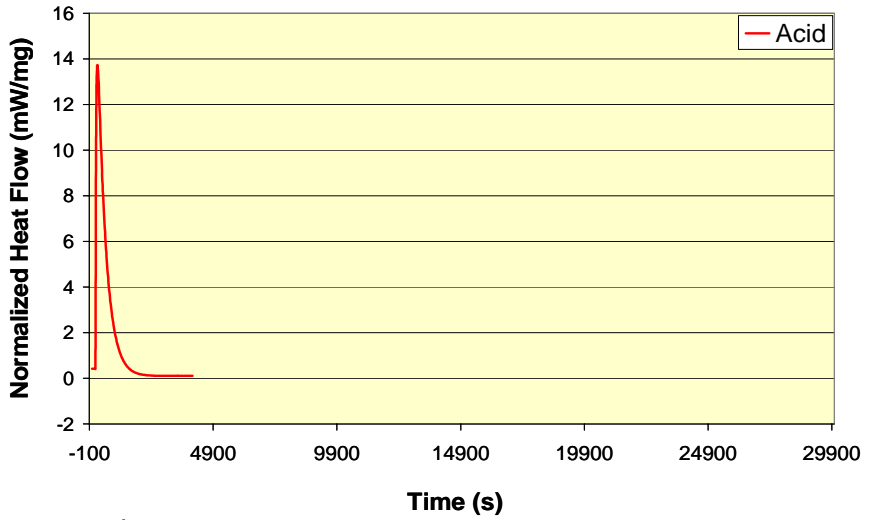

a)

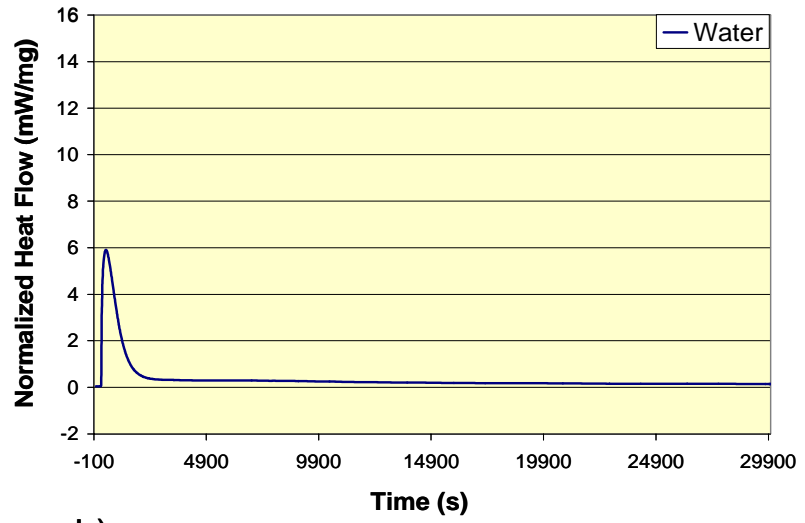

b)

Figure 2. Normalized heat flow (mW/mg) for liquid mixing of $2 \mathrm{LiBH}_{4} \mathrm{MgH}_{2}$ with a) $1 \mathrm{M} \mathrm{HCl}$ acid and b) neutral DI water at $40^{\circ} \mathrm{C}$

\section{Gas flow cell}

Figure 3. displays the normalized heat flow (mW/mg) for the $2 \mathrm{LiBH}_{4}: \mathrm{MgH}_{2}$ reaction with liquid water in a mixing cell compared with water vapor in a gas flow cell. The qualitative difference observed by heat flow is believed to be due to the difference in gas/solid versus liquid/solid interfacial reactions and is currently under further investigation. Multiple heat releasing events were observed in the gas flow experiments indicating that the reaction proceeded in a stepwise manner or a spallation type process. The reaction with $30 \%$ relative humidity air resulted in $\mathrm{LiB}(\mathrm{OH})_{4}$ and remaining $\mathrm{MgH}_{2}$ products with a total energy release of $268 \mathrm{~kJ} / \mathrm{mol}$.

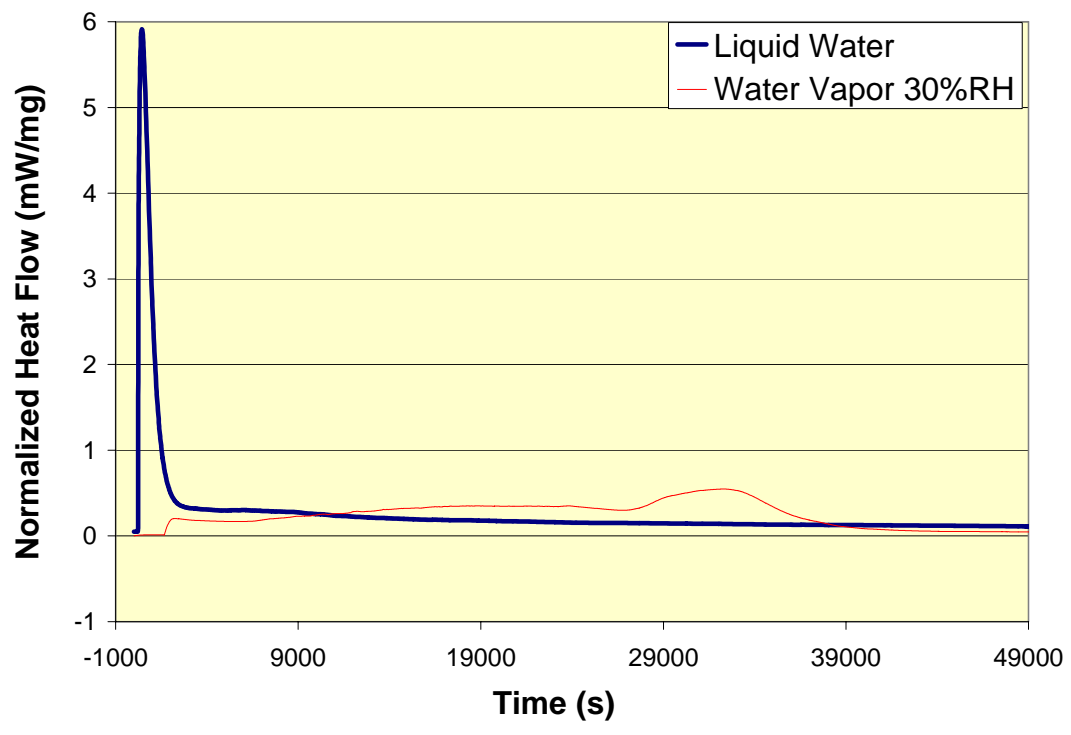


Figure 3. Normalized heat flow (mW/mg) during hydrolysis/oxidation of $2 \mathrm{LiBH}_{4}: \mathrm{MgH}_{2}$ with liquid water at $40^{\circ} \mathrm{C}$ and with $30 \%$ relative humidity air at $40^{\circ} \mathrm{C}(10 \mathrm{ml} / \mathrm{min}$ flow rate $)$.

\section{DISCUSSION}

Table 2. summarized the liquid mixing and gas flow reaction experiments performed on the both pure component $\mathrm{LiBH}_{4}$ and $\mathrm{MgH}_{2}$ as well as the destabilized mix $\left(2 \mathrm{LiBH}_{4}: \mathrm{MgH}_{2}\right)$. Overall, in both the liquid mixing and gas flow reactions the trend is for a lower measured energy compared to the thermodynamically predicted reactions. A corollary to this is that the actual observed products do not match those predicted from thermodynamics and often have a significant degree of amorphous character.

An apparent anomaly in Table 2. for the reaction of liquid water with $\mathrm{LiBH}_{4}$ is the actual measured $\Delta \mathrm{H}(-320 \mathrm{~kJ} / \mathrm{mol})$ which is greater than the reaction for the theoretical lowest energy product predicted from the thermodynamic database. However the $\Delta \mathrm{H}$ for the theoretical product does not take into consideration the heat of dissolution in aqueous solution of $\mathrm{LiBH} 4 \rightarrow \mathrm{Li}(+)+\mathrm{BH}_{4}(-)$ with an enthalpy of $\sim 43 \mathrm{~kJ} / \mathrm{mol}$ at $40^{\circ} \mathrm{C}[4]$. In addition, the actual products were found to be an amorphous lithium plus boron hydroxide product indicating a different reaction pathway occurred than was predicted. The hydrolysis and oxidation of magnesium hydride was found to be extremely slow with starting material found in the final product and total measured heat of reaction less than 1\% of those experimentally predicted. This is believed to be due to the relatively high stability of the $\mathrm{Mg}(\mathrm{OH})_{2}$ surface layer $(\Delta \mathrm{H}$ formation $334 \mathrm{~kJ} / \mathrm{mol}$ ).

Table 2. Experimental versus Theoretical Products and Reaction Energies

\begin{tabular}{|c|c|c|c|}
\hline Material System & $\begin{array}{l}\text { Environmental } \\
\text { Exposure }\end{array}$ & $\begin{array}{l}\text { Theoretical Product } \\
\Delta \mathrm{H}(\mathrm{kJ} / \mathrm{mole}) \text { at } 40^{\circ} \mathrm{C}\end{array}$ & $\begin{array}{c}\text { Actual Product } \\
\Delta \mathrm{H}(\mathrm{kJ} / \mathrm{mole}) \text { at } 40^{\circ} \mathrm{C}\end{array}$ \\
\hline $\mathrm{LiBH}_{4}$ & $\mathrm{H}_{2} \mathrm{O}$ (liquid) & $\begin{array}{l}\mathrm{LiBO}_{2} \\
-258\end{array}$ & $\begin{array}{c}\text { Amorphous } \mathrm{Li}+\mathrm{B}(\mathrm{OH})_{3} \\
-320\end{array}$ \\
\hline $\mathrm{MgH}_{2}$ & $\mathrm{H}_{2} \mathrm{O}$ (liquid) & $\begin{array}{l}\mathrm{Mg}(\mathrm{OH})_{2} \\
-278\end{array}$ & $\begin{aligned} & \mathrm{Mg}(\mathrm{OH})_{2}+\mathrm{Mg}+\mathrm{MgH}_{2} \\
&<-1\end{aligned}$ \\
\hline $\mathrm{LiBH}_{4} * 1 / 2 \mathrm{MgH}_{2}$ & $\mathrm{H}_{2} \mathrm{O}$ (liquid) & $\begin{array}{l}\mathrm{LiOH}+1 / 2 \mathrm{Mg}(\mathrm{OH})_{2}+\mathrm{H}_{3} \mathrm{BO}_{2} \\
-445\end{array}$ & $\begin{array}{c}\text { Amorphous } \mathrm{Li}+\mathrm{LiB}(\mathrm{OH})_{4}+ \\
\mathrm{Mg}(\mathrm{OH})_{2}+\text { Lithium borate } \\
\text { hydrates } \\
-223\end{array}$ \\
\hline $\mathrm{LiBH}_{4}$ & $\begin{array}{l}\mathrm{H}_{2} \mathrm{O} \text { (gas) }+ \\
\mathbf{O}_{2} \text { air }\end{array}$ & $\begin{array}{l}\mathrm{LiOH}+\mathrm{H}_{3} \mathrm{BO}_{2} \\
-1386\end{array}$ & $\begin{array}{c}\mathrm{LiB}(\mathrm{OH})_{4}+\mathrm{H}_{6} \mathrm{~B}_{2} \mathrm{O}_{6}+ \\
\mathrm{LiB}(\mathrm{OH})_{2}\left(\mathrm{O}_{2}\right) \\
-352\end{array}$ \\
\hline $\mathrm{LiBH}_{4}$ & $\begin{array}{l}\mathrm{H}_{2} \mathrm{O} \text { (gas) }+ \\
\text { Argon }\end{array}$ & $\begin{array}{l}\mathrm{LiBO}_{2} \\
-344\end{array}$ & $\begin{array}{c}\mathrm{LiB}(\mathrm{OH})_{4} \\
-340\end{array}$ \\
\hline $\mathrm{MgH}_{2}$ & $\begin{array}{l}\mathrm{H}_{2} \mathrm{O} \text { (gas) }+ \\
\mathbf{O}_{2} \text { air }\end{array}$ & $\begin{array}{l}\mathrm{Mg}(\mathrm{OH})_{2} \\
-848\end{array}$ & $\begin{array}{c}\mathrm{Mg}+\mathrm{MgH}_{2} \\
<-1\end{array}$ \\
\hline $\mathrm{LiBH}_{4} * 1 / 2 \mathrm{MgH}_{2}$ & $\begin{array}{l}\mathrm{H}_{2} \mathrm{O} \text { (gas) }+ \\
\mathbf{O}_{2} \text { air }\end{array}$ & $\begin{array}{l}\mathrm{LiOH}+1 / 2 \mathrm{Mg}(\mathrm{OH})_{2}+\mathrm{H}_{3} \mathrm{BO}_{2} \\
-1206\end{array}$ & $\begin{array}{c}\mathrm{LiB}(\mathrm{OH})_{4}+\mathrm{MgH}_{2} \\
-268\end{array}$ \\
\hline
\end{tabular}


When humid air is used as the carrier gas, there are two competing reactions; that between the material and oxygen and between the material and water vapor. Consideration of these effects independently using thermodynamic database revealed that the air oxidation was the predicted dominant reaction. As a way to experimentally verify the effect of oxidation versus gas phase hydrolysis, argon as a carrier gas with $30 \%$ relative humidity was used in the $\mathrm{LiBH}_{4}$ material system as a control experiment. With humid air as the gas reactant, the predicted energy release of $-1386 \mathrm{~kJ} / \mathrm{mol}$ comes from oxidation, while use of the humid argon carrier gas predicts an energy release of $-344 \mathrm{~kJ} / \mathrm{mol}$ from gas phase hydrolysis. Experimentally, the identity of the major product was the same from the two reactions, $\mathrm{LiB}(\mathrm{OH})_{4}$. However the reaction that occurred in the processes of air has small amounts of $\mathrm{H}_{6} \mathrm{~B}_{2} \mathrm{O}_{6}$ as well as $\mathrm{LiB}(\mathrm{OH})_{4}\left(\mathrm{O}_{2}\right)$ but exhibited only a slight increase in the energy released. The results of maximum heat flow during environmental exposure scenarios are presented in Figure 4 for both mixing with liquid water and gas flow experiments in humid air and argon atmospheres. The data indicate that it is not the oxidative effects of oxygen which are of greatest risk for promoting energy release in the $2 \mathrm{LiBH}_{4}: \mathrm{MgH}_{2}$ system, but it is the presence of gaseous oxygen itself which can combine with the released hydrogen from hydrolysis that is the real danger in environmental exposure scenarios.

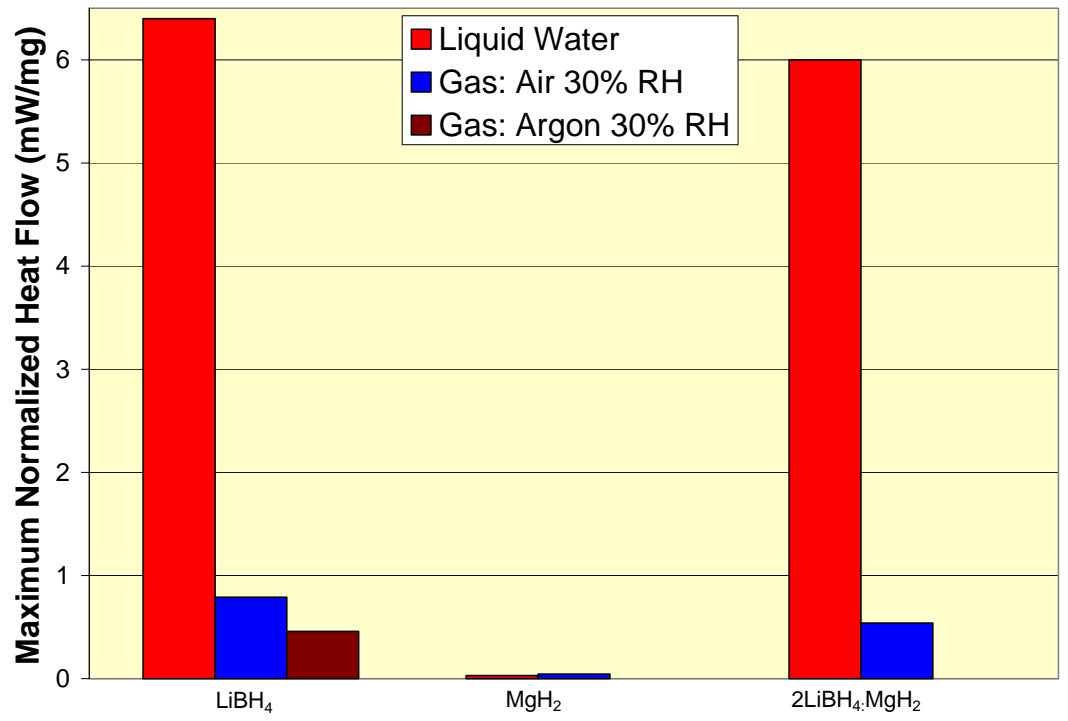

Figure 4. Maximum rate of heat flow during hydrolysis at $40 \mathrm{oC}$ with liquid water, gas flow air with $30 \%$ relative humidity, and gas flow argon with $30 \%$ relative humidity.

\section{CONCLUSIONS}

The environmental reactivity of the destabilized $2 \mathrm{LiBH}_{4}: \mathrm{MgH}_{2}$ system was most sensitive to water hydrolysis reactions with the destabilized mix following the behavior of the pure $\mathrm{LiBH}_{4}$ component due to the relative lack of $\mathrm{MgH}_{2}$ hydrolysis reactivity. The experimentally observed products often contained significant amorphous content which is not reflected in the thermodynamic predictions. The maximum normalized heat flow for this material under likely environmental exposure scenarios occurred under liquid water hydrolysis conditions (6 mW/mg). 


\section{ACKNOWLEDGMENTS}

The authors would like to acknowledge Arthur Jurgensen for X-ray Diffraction measurement assistance and analysis. Henry Sessions of the SRNL hydrogen processing group is gratefully acknowledged for assistance in gas analysis. This project is financially supported by DOE contract Xxx.. WSRS.. .

\section{REFERENCES}

1. Vajo, J.J. and G.L. Olson, Hydrogen storage in destabilized chemical systems. Scripta Materialia, 2007. 56(10): p. 829-834.

2. Satyapal, S., et al., The US Department of Energy's National Hydrogen Storage Project: Progress towards meeting hydrogen-powered vehicle requirements. Catalysis Today, 2007. 120(3-4): p. 246-256.

3. Ren, R.M., et al., Stability of lithium hydride in argon and air. Journal of Physical Chemistry B, 2006. 110(21): p. 10567-10575.

4. HSC Chemistry: Outokumpu Research Oy, Finland. www.outokumpu.com/hsc.

5. Kojima, Y., K.I. Suzuki, and Y. Kawai, Hydrogen generation by hydrolysis reaction of magnesium hydride. Journal of Materials Science, 2004. 39(6): p. 2227-2229. 